\title{
Critical success factors when going global: Agribusiness co-operative growth
}

\author{
T.O.R. MACDONALD and J. S. ROWARTH \\ Agribusiness, Waikato Management School, University of Waikato, PB 3240 Hamilton
}

JRowarth@waikato.ac.nz

\begin{abstract}
Agricultural co-operatives make a significant contribution to New Zealand's economy, but "going global" involves the realities of conducting business at an international scale with potential for significant risk exposure in both the short and long run. This paper provides a case study analysis detailing the critical success factors for agribusiness co-operatives growing internationally. The paper studies the strategies of three New Zealand agri-co-operatives with international business ventures (Ravensdown, the Dairy Goat Co-operative, and Fonterra). The case data suggests international success is a factor of sufficient access to capital, strong customer relationships, value chain management and maintaining control through competitive advantage.
\end{abstract}

Keywords: Case study, co-operative, critical success factors, international growth, strategy.

\section{Introduction}

Agribusiness co-operatives have significant market capitalisation within the New Zealand economy. The effective use of co-operative business models has enabled key agricultural industries to overcome inefficient market conditions, specifically perishability and post-production technology requirements (Sporleder \& Boland 2011). International strategy is a default component of New Zealand agribusiness stemming from the limited scale within New Zealand's domestic market. Fundamentally, agribusiness internationalisation remains as it always has, however several aspects of the international market place have changed. Demand for high quality protein is increasing exponentially in emerging markets. At the same time product footprint, sustainability and traceability have gained importance for the modern consumer; however low cost nutrition is still a priority. The need for agribusiness to remain competitive against a growing number of large international firms is still paramount. The strategies chosen to internationalise co-operatives are varied, however, several critical success factors have been identified which assist cooperative internationalisation to maximise economic returns to shareholders. These critical success factors have been determined by analysing three New Zealand co-operatives: Ravensdown fertiliser co-operative, the first trans-Tasman co-operative, responsible for supply and distribution of fertiliser in New Zealand and Australia; the Dairy Goat Co-operative which exports world leading infant formula to 20 countries; Fonterra Co-operative Group, New Zealand's largest raw milk processor and responsible for one third of all internationally traded dairy products. This paper details what it takes for international co-operative growth within the context of the basic challenge (Rowarth et al. 2013).

\section{Approach}

An academic literature review examining international growth strategy was used within the framework of Lewis et al. (1991) to analyse the three companies, Ravensdown, Dairy Goat Co-operative (DGC) and Fonterra. Using the framework, individual case studies were prepared from company reports and interviews with key industry people. Main findings were examined in cross case discussion to determine the critical success factors.

\section{Critical Success Factors}

In examining the case study framework (Lewis et al. 1991) and the information from the three cooperatives, the following factors were identified as critical to successful international growth: (1) Control (2) Sufficient access to capital (3) Value chain analysis (4) Customer relationships (5) Sustainable point of difference and (6) Effective governance and communication. Cultural understanding is often overlooked by firms in the off-shoring process due to its intangible nature. A broad cultural understanding is required in support of the above success factors. Integrating both tangible and intangible success factors (Ng \& Kee 2012) underpins a sustainable international business venture. Critical success factors have been summarised in Table 1.

\section{Control}

Ensuring suitable measures of control over capital, infrastructure and product within the foreign market is critical to returning a profit for the co-operative with 
a demand driven supply chain (Budd et al. 2012). Control in the international market is largely driven by the management structures and distribution strategies of the international venture. A demand driven supply chain operates successfully based upon visibility, infrastructure, coordination and optimisation (Budd et al. 2012). The three co-operatives have used different methods to obtain control. Ravensdown maintains control of the foreign market through the existing domestic market management structure, choosing not to institutionalise cost in the foreign market (M. Manning, pers. comm. 2013) This allows greater cost control and maximum returns to shareholders in two ways: (1) Ravensdown saves on replicating administration and additional staffing cost; (2) operating effectively as one market allows fixed operating cost to be distributed over greater throughput. Ravensdown has two Australian based directors representing the market at governance level. Furthermore, Ravensdown has significant investment in international supply chain infrastructure (Ravensdown 2012) which gives the co-operative ability to optimise quality, quantity and timing.

The DGC has robust controls in place for the management of its export infant formula. The cooperative operates a subsidiary company Pacific Orient Limited, a joint venture with Orient Europharma Company, specialists in international product distribution (New Zealand Companies Office 2013). Pacific Orient Limited has two appointed Taiwanese directors in governance roles. DGC further maintains control over domestic suppliers, carefully matching supply with international demand through the use of supplier quotas. Supplier members are further controlled by the co-operative in the on-farm production of goat milk to ensure only premium product is sent to the co-operative, a provision necessary under the DGC international strategy.

The Fonterra model breaks markets into geographical segments each controlled as a separate business unit. The co-operative maintains control of international operations from global offices. Fonterra owns and operates distribution brands in the foreign markets. This ensures product is sold for premium returns. Implementation of the Fonterra "Strategy Refresh" (Fonterra 2013) has enabled Fonterra to streamline both the geographical market segmentation and the use of Fonterra brands. This streamlining provides greater control of global distributions and therefore return to member shareholders is anticipated to improve.

\section{Sufficient access to capital}

Capital has traditionally been identified as the major limitation for co-operatives to internationalise (Cook 1995). Several variations of capital structure have been used to generate sufficient pools of capital available for internationalisation. Ravensdown identified the capital limitations of the co-operative model and on the invitation of Australian farmers built an international strategy based on international co-operative membership. To raise capital, Ravensdown required Australian members to purchase shares in a short time frame. Effectively, Ravensdown used the capital of clients/farmers in the Australian market to fund the cooperative's initial cost of Australian operations.

The DGC has grown the international market with the growth of the co-operative. In doing so the co-operative has had capital available to invest in the export of larger volumes and the technology to produce significantly greater volumes of product. Hence, the DGC has an international strategy based upon the capital capabilities of the co-operative. Limiting investment in international markets and focusing on improving the value of export product, the co-operative maintains the ability to pass on highest returns to shareholders.

Fonterra has significant capital capabilities, however provisions under the co-operative model restricted the ability of Fonterra to realise free capital on the basis of share redemption risk. Redemption risk limited working capital from being used in high growth areas of the business, namely international strategy. In 2012 Fonterra amended the co-operative's capital structure, implementing a secondary market for co-operative share trading. This reduced the level of inefficient capital on the balance sheet. The capital restructuring of Fonterra allows the co-operative to implement strategic international growth more efficiently.

\section{Value chain management}

Value chain analysis and subsequent value chain management is an essential element of co-operative growth strategy. Value chain management refers to the integration of communication and organisational capability up and down the entire supply chain (Chetty $\&$ Hunt 2000). Integrating steps of the value chain ensures efficiency (New Zealand Institute of Economic Research 2012), optimising the economic value of produced goods generates higher margins, and in turn directs the profit to producers.

Ravensdown adds value for members by efficiently controlling sourcing, logistics and distribution of product and by removing volatility in the fertiliser market (Ravensdown 2012). Managing the shipping of product lowers the cost of fertiliser and captures more value for the member shareholder.

DGC has maximised product value and its returns to members by manufacturing a premium product (infant formula) and on-selling this in foreign markets for a high return. Returns to DGC shareholders are reputed to be at 
least double that of bovine dairy counterparts. DGC has further captured value for the member shareholder by operating subsidiary companies within the value chain, DGC owns Dairy Blenders Ltd and a half share of New Zealand Can Manufactures Ltd (OpenCorporates 2013). This further directs profits from the formula processing and manufacturing for export towards the co-operative members.

Fonterra maintains a strong global dairy presence, and its new international strategy integrates the value chain through developing consumer branding and specialist high value product. Maintaining and cultivating brands with consumer pull, particularly in the brand-conscious Asian markets, will be crucial for success and continued growth within the market (Gell et al. 2012). Fonterra's technical knowledge of efficient processing is anticipated to lead to higher per product profit margins which in turn will improve return to the primary producer shareholder. Further value chain analysis has led to Fonterra investing in global milk pools (e.g., China, South America). The investment in Chinese and South American farming ventures are intended to improve value by securing high quality milk closer to market (Fonterra 2013).

\section{Customer Relationships}

Management of international customer relationships are fundamental to successful international co-operative growth. Developing specific customer relationship goes beyond understanding a foreign market and focuses on the particular needs of the end user (New Zealand Trade and Enterprise 2009). It is these customer relationships that allow for improved profit margins and less fluctuation in price.

Ravensdown sells direct to customer farmers through technical sales representatives both domestically and in the Australian market. The personal sales are intended to build farmer relationship and loyalty to the co-operative. Despite this, many farmers choose dual co-operative memberships in New Zealand (i.e., they have shares in both Ravensdown and Ballance Agrinutrients). Ravensdown has improved communication with shareholders adopting "MyRavensdown", an online customer platform (Ravensdown 2012).

Table 1 Summary of the critical success factors of the three co-opratives studied.

\begin{tabular}{|c|c|c|c|}
\hline & Fonterra & Dairy Goat Co-op & Ravensdown \\
\hline Co-op membership o/s & No & No & Yes \\
\hline $\mathrm{O} / \mathrm{S}$ office & $\mathrm{Y}$ & $\mathrm{N}$ & $\mathrm{N}$ \\
\hline Value add strategy & Progressing & Core strategy & Capture value chain \\
\hline Control & $\begin{array}{l}\text { Fonterra control all offshore } \\
\text { investments with staff and } \\
\text { offices. Fonterra's global } \\
\text { presence is well managed } \\
\text { within the organisation's } \\
\text { structure. }\end{array}$ & $\begin{array}{l}\text { The DGC control input, } \\
\text { processing and output of the } \\
\text { formula process. They use } \\
\text { market relationships to control } \\
\text { the supply of formula to market } \\
\text { with little capital investment. }\end{array}$ & $\begin{array}{l}\text { Controlled the initial investment } \\
\text { by offering, } \\
\text { i) equity as payment } \\
\text { ii) Below market value } \\
\text { Same management teams for } \\
\text { both markets. } \\
\text { Investment in international } \\
\text { supply chain }\end{array}$ \\
\hline
\end{tabular}

\begin{tabular}{|c|c|c|c|}
\hline $\begin{array}{l}\text { Sufficient access to } \\
\text { capital }\end{array}$ & $\begin{array}{l}\text { High level of available capital. } \\
\text { Introduction of TAF enables } \\
\text { greater working capital }\end{array}$ & $\begin{array}{l}\text { Capital base growing with the } \\
\text { co-op. Ability to raise sufficient } \\
\text { capital growing significantly }\end{array}$ & $\begin{array}{l}\text { Capital for going global } \\
\text { provided by foreign member/ } \\
\text { farmers under } \\
\text { co-op agreement. }\end{array}$ \\
\hline Value chain management & $\begin{array}{l}\text { Being refreshed } \\
\text { New high value product lines }\end{array}$ & $\begin{array}{l}\text { High quality }=\text { High value } \\
100 \% \text { of strategy }\end{array}$ & $\begin{array}{l}\text { Supply chain inferstructure to } \\
\text { capture more value for farmers }\end{array}$ \\
\hline Relationship markets & $\begin{array}{l}\text { Slowly increasing, } \\
\text { Branding refresh to improve } \\
\text { customer interfacing. }\end{array}$ & $\begin{array}{l}\text { Increasing } \\
\text { Good branding, } \\
\text { Good quality commitment }\end{array}$ & $\begin{array}{l}\text { Strong } \\
\text { Direct to customer }\end{array}$ \\
\hline $\begin{array}{l}\text { Sustainable point of } \\
\text { differance }\end{array}$ & $\begin{array}{l}\text { Technical processing ability, } \\
\text { Scale }\end{array}$ & $\begin{array}{l}\text { Market leaders } \\
\text { Pasture fed quality }\end{array}$ & Cooperative structure \\
\hline Governance & $\begin{array}{l}\text { Broad \& complex. } \\
\text { Independents with international } \\
\text { experience. }\end{array}$ & $\begin{array}{l}\text { Limited pool of governance } \\
\text { within smaller shareholder } \\
\text { base. High performance track } \\
\text { record. }\end{array}$ & $\begin{array}{l}\text { Broad - farmer owners } \\
\text { Two Independents } \\
\text { Australian represented }\end{array}$ \\
\hline Going global & $\begin{array}{l}\text { Multi-national, start up } \\
\text { ventures, partnerships and } \\
\text { exports. Limited farmer } \\
\text { involvment }\end{array}$ & $\begin{array}{l}\text { Export based } \\
20 \text { countries } \\
\text { Asian focus } \\
\text { Farmers not involved. }\end{array}$ & $\begin{array}{l}\text { Australian only, } \\
\text { International sourcing } \\
\text { Australia pre-approved by } \\
\text { board. }\end{array}$ \\
\hline
\end{tabular}


DGC has slowly increased customer relationships in the Asian markets over the company's existence. Brand reputation and consistency achieved by the co-operative are essential to maintaining customer relationships particularly in the Asian markets.

Similarly, Fonterra is working to improve customer relationships through improved branding and marketing strategies as well as extending product offerings. The 2012 Fonterra Strategy Refresh aims to build and grow Fonterra beyond current consumer positions through improving market share and positioning of value added products (Fonterra 2013).

\section{Sustainable point of difference}

Long-term co-operative internationalisation requires a sustainable competitive advantage to differentiate the co-operative in the global market. Businesses from the New Zealand market adopt "brand New Zealand" as a competitive advantage, however this advantage must be used in conjunction with the businesses core competitive advantage to create a sustainable point of difference. In the case of Ravensdown's internationalisation, the cooperative business model itself was a point of difference to the Australian fertiliser market. Including the farmers into the co-operative model through share membership ensured a strong distribution network and provided members with economic benefits greater than those available through existing non-co-operative suppliers.

DGC's commitment to research and development has given the co-operative the world's first commercial goats' milk formula. DGC leads the goats' milk formula market through developing a niche product. The cooperative's strategy of predominately pasture fed goats further improves the quality and hence marketability to the end consumer.

The Fonterra co-operative has significant experience and technical ability to efficiently process farm gate milk supply. It is this knowledge that the co-operative is able to implement in overseas markets (China, South America) to generate product at lower cost per unit than existing competition.

\section{The role of governance and communication}

Achieving board and member coherence as well as unity of purpose is central to effective governance. Suitable governance and corporate structure increases the effectiveness of the co-operative to deliver members results in line with the co-operative purpose. Communicating with supplier shareholders to ensure common (international) vision is the defining role of co-operative boards and critical to the success of a co-operative's international strategy (Old 2012). Optimising the ratio of member to independent representation, as well as ensuring board diversity, remains a challenge as agribusiness co-operatives gain large market shares internationally (Old 2012).

Ravensdown governance anticipated the move of international co-operative expansion. Due diligence of the Australian market showed synergies for the co-operative's existing operations, particularly with product logistics. The foresight enabled governance to approve an Australian strategy promptly following invitation from Australian farmers, and assured cooperative members of the strategy's alignment with co-operative purpose. The Ravensdown board has high level of member representation ensuring effective communication lines. There are ten ward representatives from around New Zealand, two independent directors as well as two Australian board representatives (Ravensdown 2012).

DGC has a significantly smaller pool of members from which to elect governance. The co-operative has five suppliers (comprising 12.9\% of total suppliers) in governance roles (New Zealand Companies' Office 2013). This has enabled information transfer ensuring an effectively communicated strategy and vision to members. The communication of strategy enables a culture of growth for the co-operative.

Fonterra's governance structure is set with consideration of the co-operative's scale and international presence. Fonterra employs four independent directors with expertise in international markets and international business to supplement the governance of supplier shareholders. Fonterra also employs a shareholders' council to provide accountability and farmer representation during governance decisions. The shareholders council (35 members) is formed with nation-wide co-operative representation. As Fonterra's international strategy is developed, so too are the communication efforts of governance and shareholders council, a reflection of the correlation between shareholder communication and successful international strategy.

\section{Discussion}

A key issue for co-operatives as they seek to grow comes in maintaining the purpose of the co-operative, maximising throughput and ensuring members' returns (Reid 2011). The critical success factors identified in this research serve as a sound framework for conducting analysis of existing and potential international co-operative ventures in relation to maintaining co-operative purpose. With many of New Zealand's co-operatives since their initial foreign investment there is a need for strategic refreshing and a considered approach to ensuring sustainable returns in the international market for the co-operative members. International co-operative growth is a function of: 
effective control (Budd et al. 2012), sufficient access to capital (Cook 1995), a strategy to add value to product (Chetty \& Hunt 2000), commitment to customer relationships (New Zealand Trade and Enterprise 2009), strong competitive advantage (New Zealand Institute of Economic Research 2012), and sound governance (Old 2012). The ability of New Zealand agribusiness cooperatives to build international strategies including the above critical success factors will see an increase in the realised returns of farmer shareholders.

\section{ACKNOWLEDGEMENTS}

This work was supported by the University of Waikato Management School. Thanks to primary sources Mike Manning, Richard Cookson, Bill Falconer, and to Frank Scrimgeour for comments.

\section{REFERENCES}

Budd, J.; Knizek, C.; Tevelson, B. 2012. The demand-driven supply chain. Boston Consulting Group 2012. 14pp.

Chetty, S.; Hunt, C. 2000. Paths to internationalization among small to medium sized firms. European Journal of Marketing 37: 796 - 820.

Cook, M. 1995. The future of U.S. agricultural cooperatives: a neo institutional approach. American Journal of Agricultural Economics 77: 1153-1159.

Fonterra Cooperative Group. 2013 Annual Report 2012. Accessed May, 2013 www.fonterra.com/global/en/ Financial/Reports+and+Publications.

Gell, J.: Hansell, G.: Stelter, D.: Olsen, E.: Wise, A. 2012. Creating superior value in challenging times. Consumer Value Creators Report. pp. 10-14. http:// www.bcg.com/documents/file123727.pdf Accessed April 2013.
Lewis G.; Morkel A.: Hubbard G. 1991. Cases in Australian strategic management. Prentice Hall, New York, 387p.

New Zealand Companies Office. 2013 Dairy Goat Cooperative (NZ) Ltd. Accessed 14 May 2013 www. business.govt.nz/companies.

New Zealand Institute of Economic Research. 2012. Lifting export performance - Actions to drive growth in exports. New Zealand Institute of Economic Research. www.nzier.org.nz. Accessed April 2013.

New Zealand Trade and Enterprise. 2009. Playing to our strengths: creating value for Kiwi firms. Accessed: 7 May 2013. www.nzte.govt.nz.

Ng, H.; Kee, D. 2012. Development of Intangible Factors for SME Success in a Developing Country. International Journal of Academic Research in Business and Social Sciences 2: 189-213.

Old, K. 2012. The roles of co-operative dairy company boards. Primary Industry Management 16: 23-25.

OpenCorporates. 2013. Dairy Goat Co-operative (NZ) Ltd. Accessed 20 May 2013, from http:// opencorporates.com/companies/nz/421398.

Ravensdown. 2012. Annual Report 2012. Accessed February 2013, www.ravensdown.co.nz.

Reid, D. 2011. How do dairy cooperatives grow for farmer benefit. New Zealand Nuffield Farming Scholarship Trust. www.nuffield.org.nz.

Rowarth, J.S.; Scott, A.P.; Macdonald, T.O.R.; Wilson, S.C.; Scrimgeour, F.G. 2013. Critical success factors when going global: the basic challenge. Proceedings of the New Zealand Grassland Association 75: 45-48.

Sporleder, T.; Boland, M. 2011. Exclusivity of agrifood supply chains: Seven fundamental economic characteristics. International Food and Agribusiness Management Review 14: 27-52. 
